\title{
RESIGNATION OF MANAGING DIRECTORS
}

Ar the annual general meeting of the shareholders of the BRITISH Journal. OF OPHThalmology the two Managing Directors, Mr. J. B. Lawford and Mr. Leslie Paton, retired from the offices which they have held for the past nine years and were succeeded by $\mathrm{Mr}$. Ernest Clarke and Mr. A. H. Levy.

The Editorial Committee wish to record the esteem and affection in which these two gentlemen are universally held by their colleagues in the management of the journal, and the indebtedness to them of ophthalmology throughout the Empire.

When Mr. Jessop died after a very brief illness in February, 1917, the journal was barely six weeks old. It was a very critical time, we had hardly found our feet, and it is not too much to say that if the management had not been immediately placed in safe hands disaster might easily have overtaken us. No words of ours are needed to remind our readers of the debt of gratitude the journal owes to Mr. Lawford and Mr. Paton. The mens provida of the former, together with his international reputation which stands for all that is best in British ophthalmology, coupled with the ungrudging hard work and business ability of the latter enabled us to ride out the storm. Now that the journal is safe, with an established reputation to maintain, and if possible to improve, we know that our readers will never forget what our late Managing Directors have done for us and for English ophthalmology.. We are glad to know that we shall continue to have the benefit of their advice at the meetings of the Editorial Committee. While all can judge of the results, only those of us who have had the privilege of working with them can appreciate to the full the amount of labour they have so ungrudgingly given.

In laying down their directorial duties they carry with them the gratitude of all their colleagues and of all who care for British ophthalmology. With Horace each may say $E t$ militavi non sine gloria. To the British Journal of Ophthalmology each has been, in the words of Homer $\pi 0 \lambda \lambda \hat{\omega} \nu \stackrel{a}{\alpha} \tau a^{\prime} \xi_{b o s} a{ }^{\prime} \lambda \lambda \omega \nu$, worth a multitude.

\section{ANNOTATIONS \\ The Opticians Bill}

On another page we have printed a précis received from the Ministry of Health of the proceedings which took place at the reception of a Deputation of the Joint Council of Qualified Opticians, with which was associated the British Optical Association, to the Minister, the Rt. Hon. Neville Chamberlain, with regard to the above Bill. 
Mr. Neville Chamberlain's reply shows that he has given the most serious consideration to the questions involved, and that he is fully impressed with the dangers of allowing opticians untrained in medical matters to deal with defects of vision. It will be remembered that the Council of British Ophthalmologists issued a report on sight-testing by opticians (Brit. Jl. of Ophthal., Vol. VI, p. 554, 1922); and it is gratifying to note that the arguments and general tenor of the Minister's reply are in concord with the views expressed in that report.

\section{"Optic Neuritis" and Cerebral Tumour}

At a recent meeting of the Royal Medico-Chirurgical Society of Glasgow there was a discussion on this subject which was instituted, apparently, by $\mathrm{Mr}$. Archibald Young, Professor of Surgery at the University, with a view of obtaining information which would be of value in surgical work. He asked the ophthalmologists a number of questions such as "What the ophthalmologist really means by optic neuritis?" and "What are the features by means of which he recognizes one type of optic neuritis from another, if, indeed, he does so?" and so on. To most of the questions asked we are afraid that the answers given by the ophthalmologists-in this instance Drs. H. W. Thomson and A. J. Ballantyne-can be fairly well summed up in the wellknown Parliamentary reply: "the answer is in the negative." The discussion of the subject was very interesting and revealed a large amount of work and thought on the part of the speakers; it will well repay perusal in the Glasgow Medical Journal of January, 1926. But we fear that the surgeon will not find much help in the conclusion that "in so far as one can be satisfied that oedematous swelling of the optic disc predominates over the retinal changes, one is justified in suspecting intracranial increase of pressure as the cause rather than a toxaemia or vascular sclerosis. In no case is it possible to assess the ocular condition until examination of the patient has revealed the presence or absence of the possible causes to which reference has already been made." Yet we do not think the ophthalmologist is at the present time in a position to make the statement any firmer than this pronouncement by $\mathrm{Dr}$. H. W. Thomson.

The following excerpt from Dr. Ballantyne's remarks is worthy of reproduction. It is as follows: "these two problems-that of the relief of the papilloedema and other pressure symptoms, and that of the removal of the neoplasm-are sometimes allowed to be confused with each other. They are two entirely different matters, and, as an oculist, I would like to make a plea for greater concentration on the simpler problem of decompression for the preservation of sight. No doubt it is a higher aim to attempt the 